Volume 5 Nomor. 1, April 2020

P -ISSN : 2541-1179, E-ISSN : 2581-1711

Ojs :http://journal.uin-alauddin.ac.id/index.php/instek/index

Email : instek@uin-alauddin.ac.id

\title{
SISTEM TERINTEGRASI PENGELOLAAN PENELITIAN KESEHATAN \\ PADA PROGRAM STUDI ILMU KESEHATAN \\ UIN ALAUDDIN MAKASSAR
}

\author{
SYAHBUDDIN ${ }^{1}$, A.MUHAMMAD SYAFAR ${ }^{2}$, GEMY NASTITY HANDAYANI ${ }^{3}$ \\ Jurusan Sistem Informasi ${ }^{1}$ \\ Jurusan Teknik Informatika ${ }^{2}$ \\ Jurusan Ilmu Farmasi ${ }^{3}$ \\ UIN Alauddin Makassar \\ E-mail: syahbudin@uin-alauddin.ac.id ${ }^{1}$, andi.syafar@uin-alauddin.ac.id ${ }^{2}$, \\ gemy.nastity@uin-alauddin.ac.id ${ }^{3}$
}

\begin{abstract}
ABSTRAK
Fokus penelitian ini adalah melakukan analisis sistem terintegrasi dalam pengelolaan penelitian kesehatan pada program studi ilmu kesehatan. Penelitian ini menggunakan metode eksperimental dengan memanfaatkan teknologi Web Service (ws). Modul-modul web service dikembangkan pada aplikasi yang telah berjalan yaitu sistem informasi kepegawaian (ws simpeg) dan sistem informasi akademik (ws siaka). Web Service siaka digunakan untuk menampilkan data mahasiswa aktif yang telah memenuhi syarat melakukan penelitian kesehatan. Sedangkan Web Service simpeg digunakan untuk memilih dosen yang akan dijadikan reviewer serta pembimbing mahasiswa dalam melakukan penelitian kesehatan. Adapun hasil dari penelitian ini adalah perancangan sistem berdasarkan analisis pada aplikasi yang berjalan serta alur proses penelitian kesehatan pada program studi ilmu kesehatan. Dengan demikian, penelitian ini diharapkan mampu menjadi acuan dalam pengembangan aplikasi yang mengelola penelitian kesehatan pada program studi ilmu kesehatan.
\end{abstract}

Kata kunci: Penelitian Kesehatan, Sistem terintegrasi, Web Service

\section{PENDAHULUAN}

Penelitian kesehatan adalah kegiatan ilmiah yang dilakukan menurut metode yang sistematik untuk menemukan informasi ilmiah/teknologi yang baru, membuktikan kebenaran atau ketidakbenaran hipotesis sehingga dapat dirumuskan teori atau suatu proses gejala alam/sosial di bidang kesehatan, dan dilanjutkan dengan menguji penerapannya untuk tujuan praktis di bidang kesehatan. 
Volume 5 Nomor. 1, April 2020

P -ISSN : 2541-1179, E-ISSN : 2581-1711

Ojs :http://journal.uin-alauddin.ac.id/index.php/instek/index

Email : instek@uin-alauddin.ac.id

Penyelenggara peneliti dan pengembangan kesehatan adalah setiap peneliti, lembaga atau badan hukum baik milik negara maupun swasta, yang menyelenggarakan penelitian dan pengembangan kesehatan. Peneliti adalah setiap orang yang bertugas melakukan penelitian (PP No. 39 Th 1995).

Penelitian dan pengembangan kesehatan bertujuan untuk memberikan masukan ilmu pengetahuan dan teknologi serta pengetahuan lain yang diperlukan untuk menunjang pembangunan kesehatan dalam rangka mewujudkan derajat kesehatan masyarakat yang optimal. Panduan etik penelitian harus dapat diterima dan diyakini kebenaran dan keabsahannya untuk dijadikan pegangan peneliti kesehatan. Panduan etik penelitian kesehatan telah disusun oleh World Medical Ascociation (WMA) dan Council for International Organization of Medical Studies (CIOMS) berkoordinasi dengan World Helth Organization (WHO). Panduan etik dijadikan rujukan dan diberlakukan di seluruh negara. Panduan etik penelitian kesehatan merupakan acuan bagi komisi etik atau pihak yang diberi kewenangan untuk menilai penelitian kesehatan apakah layak etik atau tidak.

Kegiatan penelitian kesehatan melibatkan banyak pihak yang saling terkait yaitu mahasiswa, ketua program studi, komite etik, operator komite etik, reviewer serta pembimbing. Proses penelitian kesehatan dapat ditempuh oleh mahasiswa setelah melakukan ujian proposal. Selanjutnya dokumen proposal diserahkan ke bagian akademik program studi dan diteruskan kepada komite etik guna penentuan reviewer dari penelitian mahasiswa tersebut. Jika proposal dianggap layak oleh reviewer maka komite etik mengeluarkan dokumen yang menyatakan kelayakan bagi mahasiswa untuk melanjutkan penelitian kesehatan. Adapun mahasiswa yang melakukan penelitian adalah mahasiswa yang secara sah dinyatakan aktif pada sistem informasi akademik (SIAKA), sementara reviewer dan pembimbing adalah tenaga pengajar yang data-datanya tersimpan pada sistem informasi kepegawaian (SIMPEG).

Berdasarkan uraian di atas dapat disimpulkan bahwa kegiatan penelitian kesehatan membutuhkan data mahasiswa, data dosen, proses verifikasi dokumen 
Volume 5 Nomor. 1, April 2020

P -ISSN : 2541-1179, E-ISSN : 2581-1711

Ojs :http://journal.uin-alauddin.ac.id/index.php/instek/index

Email : instek@uin-alauddin.ac.id

serta proses bimbingan secara online. Oleh karena itu, pengaksesan pada dua sistem informasi yang berbeda mutlak dilakukan untuk memastikan bahwa data mahasiswa dan dosen adalah valid. Selanjutnya data pada dokumen proposal terutama yang berkaitan dengan judul serta isi penelitian sebaiknya disimpan dan dapat menjadi acuan ataupun pertimbangan ketika ada topik penelitian sejenis. Dengan demikian dalam rangka efesiensi dan efektivitas manajemen, maka sangat perlu diperhatikan tentang proses-proses utama, data yang mengalir pada tiap proses serta pihak-pihak terkait di dalamnya. Interaksi antara pihak yang terkait dalam suatu proses seharusnya mempertimbangkan kemudahan akses data, informasi dan komunikasi. Berdasarkan uraian di atas, maka fokus penelitian ini adalah sistem terintegrasi pengelolaan penelitian kesehatan pada program studi ilmu kesehatan.

\section{METODE PENELITIAN}

Penelitian ini merupakan penelitian eksperimental dimana ruang lingkup masalah dapat dilakukan dengan metode studi pustaka (library research) dan metode pengumpulan data lapangan (field research). Tahapan analisis dilakukan untuk melihat kebutuhan sistem yang dibangun serta aplikasi-aplikasi yang telah berjalan. Dengan demikian memungkinkan untuk mengidentifikasi pola integrasi dan fungsi dalam membangun web service pada SIAKA dan SIMPEG.

\section{Sistem Terintegrasi}

Sistem informasi yang terintegrasi merupakan sebuah sistem yang memungkinkan berbagi data untuk seluruh organisasi. Dengan sebuah sistem terintegrasi, perusahaan dapat menyimpan informasi secara elektronik (Monk, E. F., 2013). Konsep dasar dari sistem terintegrasi adalah upaya untuk menyatukan beragam sistem informasi yang terdapat pada suatu unit organisasi/lembaga. Hal ini sangat bermanfaat dalam meminimalisir redudansi data serta memudahkan dalam proses autentikasi akses pada sistem yang berjalan.

Sistem integrasi (integrated system) merupakan sebuah rangkaian proses untuk menghubungkan beberapa sistem komputerisasi dan software aplikasi, baik 
Volume 5 Nomor. 1, April 2020

P -ISSN : 2541-1179, E-ISSN : 2581-1711

Ojs :http://journal.uin-alauddin.ac.id/index.php/instek/index

Email : instek@uin-alauddin.ac.id

secara fisik maupun secara fungsional. Sistem terintegrasi menggabungkan komponen sub-sub sistem ke dalam satu sistem dan menjamin fungsi-fungsi dari sub sistem tersebut sebagai satu kesatuan sistem.

\section{Web Service}

Web service (ws) adalah suatu sistem perangkat lunak yang dirancang untuk mendukung interoperabilitas dan interaksi antar sistem pada suatu jaringan (Kurniawan, 2005). Sedangkan menurut Priambodo, web service merupakan sekumpulan fungsi program untuk melakukan pekerjaan tertentu yang dalam hal ini tentu manipulasi data berpa mengambil, menambahkan atau mengubah data (Priambodo, 2010). Menurut W3C, Web service memiliki interface yang dideskripsikan dalam format yang dapat dibaca oleh mesin. Sistem yang beragam dapa berinteraksi dengan web service menggunakan pesan SOAP yang umumnya dikirim melalui HTTP dalam bentuk XML (W3C, 2014). Tetapi secara umum, web service tidak terbatas hanya pada standar SOAP saja (Richards, Robert. 2006).

\section{Sistem informasi akademik}

Sistem informasi akademik (SIAKA) adalah sistem informasi yang dibangun untuk manajemen kegiatan administrasi akademik baik yang berjalan pada jaringan online maupun offline. Adapun aktivitas utama yang berkaitan dengan siaka adalah kegiatan penerimaan mahasiswa baru, penerbitan nim, registrasi dan heregistrasi, penunjukan dosen pembimbing, pembuatan kurikulum, pembuatan kartu rencana studi, pembuatan kelas, penjadwalan kuliah, penilaian hasil studi, pengujian proposal, proses yudisium, kelulusan mahasiswa serta pelaporan pada PD DIKTI. Adapun kegiatan yang berkaitan dengan sistem yang dianalisis pada penelitian ini adalah aktivitas pengujian proposal, penetapan reviewer, penetapan dosen pembimbing serta proses monitoring penelitian mahasiswa.

\section{Sistem Informasi Kepegawaian}

Sistem informasi kepegawaian (SIMPEG) merupakan aplikasi pada suatu instansi yang dapat digunakan untuk melakukan penginputan, pengawasan dan monitoring data-data kepegawaian. Data utama yang berkaitan dengan pegawai antara lain 
Volume 5 Nomor. 1, April 2020

P-ISSN : 2541-1179, E-ISSN : 2581-1711

Ojs :http://journal.uin-alauddin.ac.id/index.php/instek/index Email : instek@uin-alauddin.ac.id

adalah data pribadi, riwayat pendidikan, riwayat penelitian, serta data pangkat dan jabatan. Adapun kegiatan yang berkaitan dengan sistem yang dianalisis pada penelitian ini adalah aktivitas pengujian proposal, dan aktivitas pembimbingan pada penelitian mahasiswa.

\section{HASIL DAN PEMBAHASAN}

\section{Alur Proses yang Berjalan}

Alur proses pada gambar di bawah ini adalah alur proses penelitian kesehatan pada program studi ilmu kesehatan di Universitas Islam Negeri Alauddin Makassar. Alur proses dibangun berdasarkan aktivitas pengguna serta dokumen dan formulir yang terkait pada kegiatan penelitian kesehatan.

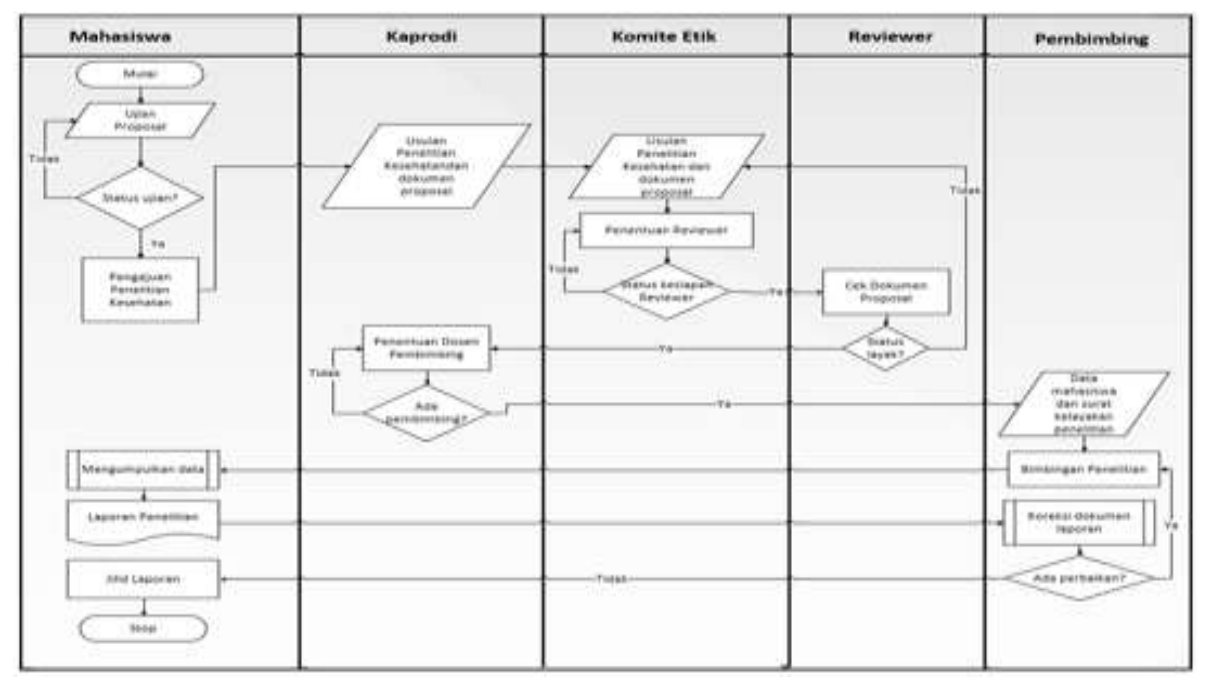

Gambar 1. Alur Proses Rancangan

Pada gambar di atas dapat dilihat bahwa pihak utama dari penelitian kesehatan adalah mahasiswa dan dosen. Sementara dalam pandangan sistem terintegrasi, pihak-pihak tersebut akan dianggap sebagai pengguna yang memiliki akses yang berbeda pada sebuah sistem. Perbedaan hak akses terlihat jelas pada status dosen, dimana dosen memiliki akses bisa sebagai ketua program studi, reviewer ataupun sebagai pembimbing penelitian. 
Volume 5 Nomor. 1, April 2020

P -ISSN : 2541-1179, E-ISSN : 2581-1711

Ojs :http://journal.uin-alauddin.ac.id/index.php/instek/index

Email : instek@uin-alauddin.ac.id

\section{PEMBAHASAN}

Hasil analisis sistem terintegrasi pada penelitian ini berfokus pada hubungan antara hak akses, aplikasi yang berjalan dan modul web service yang akan dibangun. Adapun aplikasi pada manajemen kampus Universitas Islam Negeri Alauddin Makassar yang dapat diintegrasikan adalah aplikasi single sign on, sistem informasi akademik dan sistem informasi kepegawaian. Rancangan sistem terintegrasi ditampilkan pada gambar di bawah ini.

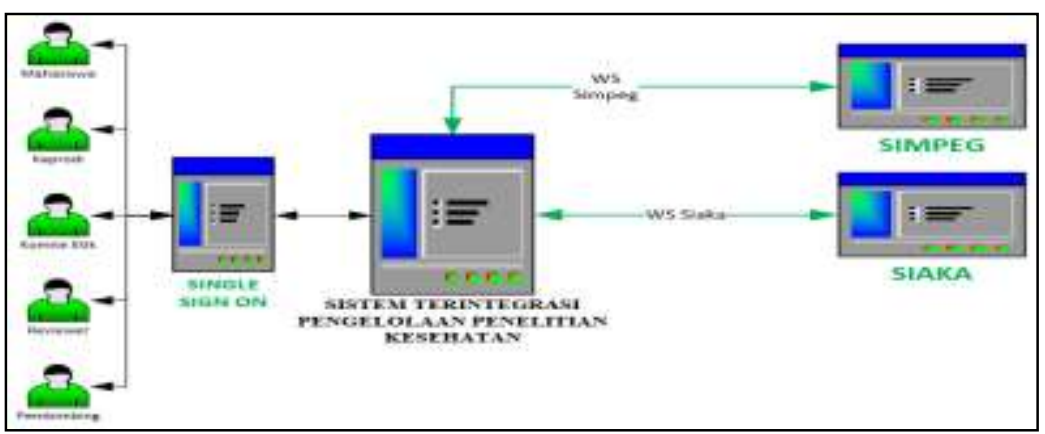

Gambar 1 Rancangan sistem terintegrasi

Berdasarkan gambar di atas terlihat jelas bahwa untuk mengelola penelitian kesehatan pada prodi ilmu kesehatan diperlukan pengembangan aplikasi baru. Data yang mengalir pada aplikasi tersebut adalah data yang bersumber dari aktivitas penelitian kesehatan dan juga data yang bersumber dari aplikasi yang telah berjalan. Data aktivitas penelitian dapat berupa data pengajuan izin penelitian, data proses verifikasi proposal, penentuan reviewer, penentuan pembimbing serta data proses pembimbingan. Sementara data yang terkait dengan data mahasiswa dan data dosen, maka dapat ditempuh dengan mengembangkan web service. Terdapat dua web service yang dikembangkan pada penelitian ini yaitu web service pada aplikasi SIMPEG (ws simpeg) dan web service pada aplikasi SIAKA (ws siaka). Secara umum ws simpeg menyiapkan modul untuk akses biodata dosen, data pangkat serta data jabatan. Sedangkan ws siaka, digunakan untuk membuat modul yang dapat mengakses biodata mahasiswa dan data bimbingan tugas akhir. 
Volume 5 Nomor. 1, April 2020

P -ISSN : 2541-1179, E-ISSN : 2581-1711

Ojs :http://journal.uin-alauddin.ac.id/index.php/instek/index Email : instek@uin-alauddin.ac.id

Dalam rangka memudahkan untuk melihat hubungan antara aktivitas, hak akses, penggunaan aplikasi dan web service maka pada penelitian ini akan diberikan nilai 1 untuk akses aplikasi maupun web service dan 0 untuk aktivitas yang tidak berkaitan dengan aplikasi ataupun web service. Pada sistem terintegrasi hubungan tersebut ditampilkan pada tabel di bawah ini.

Tabel 1 Hubungan antara hak akses, aplikasi dan web service.

\begin{tabular}{|l|l|c|c|c|c|}
\hline \multirow{2}{*}{ Hak akses } & \multirow{2}{*}{ Aktivitas } & \multicolumn{2}{|c|}{ Aplikasi } & \multicolumn{2}{c|}{ Web Service(WS) } \\
\cline { 3 - 6 } & & Sso & $\begin{array}{c}\text { Sistem } \\
\text { Terintegrasi }\end{array}$ & $\begin{array}{c}\text { WS } \\
\text { SIAKA }\end{array}$ & $\begin{array}{c}\text { WS } \\
\text { SIMPEG }\end{array}$ \\
\hline \multirow{3}{*}{ Mahasiswa } & Mengaiukan penelitian & 1 & 1 & 1 & 0 \\
\cline { 2 - 6 } & Proses Bimbingan & 1 & 1 & 1 & 1 \\
\cline { 2 - 6 } & Membuat Laporan Penelitian & 1 & 1 & 1 & 1 \\
\hline \multirow{2}{*}{ Kaprodi } & Menerima Pengaiuan Penelitian & 1 & 1 & 1 & 1 \\
\cline { 2 - 6 } & Menentukan dosen pembimbing & 1 & 1 & 1 & 1 \\
\hline \multirow{2}{*}{ Komite Etik } & Menerima Pengajuan penelitian & 1 & 1 & 1 & 0 \\
\cline { 2 - 6 } & Menentukan reviewer & 1 & 1 & 1 & 1 \\
\hline \multirow{2}{*}{ Reviewer } & Memeriksa dokumen proposal & 1 & 1 & 1 & 1 \\
\hline Pembimbing & Bimbingan Penelitian & 1 & 1 & 1 & 1 \\
\hline & Total Nilai & 9 & 9 & 9 & 7 \\
\hline
\end{tabular}

Berdasarkan data pada tabel hubungan antara hak akses, aplikasi dan web service diketahui bahwa untuk mengakses sistem terintegrasi maka pengguna harus mengakses aplikasi SSO dan ws siaka. Sementara untuk ws simpeg, persentase aksesnya sebanyak 77,78\% dari keseluruhan total aktivitas yang ada. Meskipun tidak mencapai persentase $100 \%$, akan tetapi pengembangan modul ws simpeg tetaplah memperhatikan teknologi web service yang tepat sebagaimana pentingnya pada modul ws siaka. Dengan demikian pengembangan sistem terintegrasi untuk pengelolaan penelitian kesehatan pada prodi ilmu kesehatan dapat dengan mudah diadopsi meskipun pada SIAKA dan SIMPEG yang beragam.

\section{IV.KESIMPULAN}

1. Rancangan aplikasi baru pada sistem terintegrasi pada penelitian ini dapat mengadopsi aplikasi-aplikasi yang telah berjalan pada suatu organisasi meskipun aplikasi tersebut dikembangkan dengan platform yang berbeda. 
Volume 5 Nomor. 1, April 2020

P -ISSN : 2541-1179, E-ISSN : 2581-1711

Ojs :http://journal.uin-alauddin.ac.id/index.php/instek/index

Email : instek@uin-alauddin.ac.id

2. Penggunaan teknologi web service dapat menghilangkan duplikasi (redudansi) data sehingga dapat menghemat media penyimpanan.

3. Teknologi single sign on, memberikan kemudahan dalam manajemen hak akses bagi pengguna pada aplikasi-aplikasi di sistem terintegrasi.

\section{DAFTAR PUSTAKA}

Alan D. dkk. 2015. Systems Analysis and Design: An Object-Oriented Approach with UML 5th Edition. Wiley Inc.

Eko, I. 2012. Sistem Bisnis Terintegrasi, Seri 999 E-Artikel Sistem Dan Teknologi Informasi

G. Tia, T. David G., D. Pabitra, G. Tseganeh Z., H. Jeffery S. Integrating hydrologic modeling web services with online data sharing to prepare, store, and execute hydrologic models. Elsevier. 2020. Journal of Environmental Modelling and Software 130 (2020) 104731

Guardian Y., dkk. 2016. Integrasi Sistem Informasi: Akses Informasi Sumber Daya Fasilitas Kesehatan dalam Pelayanan Rujukan. Jurnal Sisfo Vol. 06 No. 01 (2016) 49-62

H. Alexis, S. Frank. Composition of heterogeneous web services: A systematic review. Graduate Program in Computer Science, Dept. of Informatics and Statistics, Federal University of Santa Catarina, Florianópolis, Brazil. Elsevier. 2016. Journal of Network and Computer Applications 143 (2019) 89-110

I Nengah S., dkk. 2013. Pengembangan Sistem Terintegrasi Untuk Panduan Pariwisata Berbasis Mobile Sebagai Daya Dukung Peningkatan Pariwisata Di Kabupaten Buleleng. Jurnal Sains dan Teknologi ISSN: 2303-3142 Vol. 2, No. 2, Oktober 2013.

K. Marlen Komorowski, C. Paulien, W. Van den Broeck, B. Olivier. Lowering the barriers for online cross-media usage: Scenarios for a Belgian single sign-on solution. Elsevier. 2016. Journal of Telematics and Informatics 33 (2016) 916-924

L. Ignacio, M. Cristian, Z. Alejandro, M. Tim A, G. Tor-Morten. Discovering web services in social web service repositories using deep variational autoencoders. Elsevier. 2020. Journal of Information Processing \& Management Volume 57, Issue 4

L. Jingming, L. Nianping, A. Kereshmeh, P. Jinqing, W. Zhibin Wua, C. Haijiao. Integration of Building Information Modeling and Web Service Application Programming Interface for assessing building surroundings in early design stages. Elsevier. 2019. Journal of Building and Environment 153 (2019) 91-100

L. Xing, L. Jiqiang, W. Wei, Z. Sencun. Android Single Sign-On Security: Issues, Taxonomy and Directions. Elsevier. 2018. Journal of Future Generation Computer Systems

PP No. 39 Th 1995. Peraturan Pemerintah Republik Indonesia Nomor 39 Tahun 1995 Tentang Penelitian Dan Pengembangan Kesehatan 